\title{
NOTES
}

\section{A SUGGESTED ROLE FOR REBUTTABLE PRESUMPTIONS IN ANTITRUST RESTRAINT OF TRADE LITIGATION}

The United States, having abandoned its contention that the restraints in the present case are per se violations of the Sherman Act, now urges " a standard of presumptive illegality," presumably on the basis of a showing that a product has been distributed by means of arrangements for territorial exclusivity and restricted retail and wholesale customers. We do not consider this additional subtlety which was not advanced in the trial court. The burden of proof in antitrust cases remains with the plaintiff, deriving such help as may be available in the circumstances from particularized rules articulated by law-such as the per se doctrine. United States v. Arnold, Schwinn \& Co.'

While the burden of proof is a significant aspect of adjudication in every field of law, ${ }^{2}$ perhaps nowhere as in the area of civil antitrust restraint of trade litigation is the allocation of the burden such a central element in each controversy. Yet because the burden of proof in restraint of trade cases is allocated by means of rules with substantive content as well, the question of the procedural adequacy of those rules is largely overlooked.

The basic supposition underlying enforcement of section 1 of the Sherman $\mathrm{Act}^{3}$ is that it prohibits only those business practices which threaten to impose unreasonable restraints on trade. Although such an interpretation was at first rejected by the courts, ${ }^{4}$ it is true, as

\footnotetext{
1. 388 U.S. 365,374 n.4 (1967).

2. Courts often resort to burden of proof rules because:

[p]olieies can be promoted or stifled smoothly, quietly, and without controversy. This befits judicial decorum . . . . Hence burden-of-proof rules can be effective levers for law reform, operating with both little friction and little greasing. Krier, Environmental Litigation and the Burden of Proof, LAW AND THE ENvironment 108 (M. Baldwin \& J. Page eds. 1970).

3. 15 U.S.C. $1-7$ (1970).

4. In one of the earliest Sherman Act cases, United States v. Trans-Missouri Freight Ass'n, 166 U.S. 290 (1897), the Court stated:
}

It is now . . . urged that the statute, in declaring illegal every combination in the form of trust or otherwise, or conspiracy in restraint of trade or commerce, does not mean what the language used therein plainly imports, but that it only means to declare 
Justice Brandeis later pointed out, that practically all commercial agreements result in some form of trade restraint. ${ }^{5}$ The question before the courts in restraint of trade suits, therefore, is presently conceived as being whether the challenged business activity, viewed in the light of reason, and after a consideration of those effects which injure competition and those which work some public benefit, should be deemed an unreasonable restraint on industrial competition. Upon the party initiating such a suit is placed a procedural burden, the "burden of going forward" - that is, the plaintiff must present evidence to support the basic allegation of the complaint. More important, the same party generally must discharge the "burden of persuasion," demonstrating by a preponderance of the evidence that an unreasonable restraint is being effected. ${ }^{6}$ Thus, the typical suit involves the presentation by the Government or by a private party plaintiff of a massive collection of material, a presentation by the defendant of equally massive amounts of rebuttal material, followed by an exhaustive legal-economic analysis of all the evidence by the court. ${ }^{7}$ However, after the analysis of a particular business activity has repeatedly resulted in a finding that the activity is, on the whole, pernicious, the courts adopt a per se rule as to that activity, and hold that such practice, whenever it is shown to have occurred, is per se a violation of the antitrust laws. When the per se rule controls, the defendant is not permitted to present evidence in rebuttal, no weighing of the activity's harmful and benign effects is done, and the burden of persuasion originally allocated to the plaintiff is conclusively inferred to have been satisfied by the mere showing that the defendant

illegal any such contract which is in unreasonable restraint of trade, while leaving all others unaffected by the provisions of the act. . . . The term is not of such limited significance. Id. at 327-38.

5. Every agreement concerning trade, every regulation of trade, restrains. To bind, to restrain, is of their very essence. The true test of legality is whether the restraint imposed is such as merely regulates and perhaps thereby promotes competition or whether it is such as may suppress or even destroy competition. To determine that question the Court must ordinarily consider the facts peculiar to the business to which the restraint is applied; its condition before and after the restraint was imposed; the nature of the rcstraint and its effect, actual or probable. Board of Trade v. United States, 246 U.S. 231,238 (1918).

6. See generally C. McCormick, LAW OF EvidENCE 306-22 (1954).

7. Prolonged proceedings and a massive record are almost inevitable if an antitrust controversy is carried to court; for the rules of law that have been developed, with respect to both the offense and the proof which may be adduced, generally permit the cntire history of a major company or industry to be placed in issue. McAllister, The Big Case: Procedural Problems in Antitrust Litigation, 64 HARv. L. REv. 27 (1950). 
has engaged in the proscribed conduct.

Considering the judiciary's flexibility in moving from the socalled "rule of reason" to the application of a per se prohibition, it is surprising to discover that the courts are unwilling to consider any intermediate position between the "rule of reason" and the per se rule. Such an intermediate position would logically be filled by the development of rebuttable presumptions of illegality. ${ }^{8}$ Perhaps such a position has been ignored because the courts view the mixed conclusions of fact and law that embody the "rule of reason" and the per se rule as having substantive, or fact-weighing, effects only and neglect the fact-producing-that is, the procedural and evidentiary-elements that are also inherent in the rules. ${ }^{9} \mathrm{~A}$ second reason that such presumptions have not been utilized may be the open question which still embroils the experts in the law of evidence as to the substantive weight such presumptions should possess. ${ }^{10}$ Finally, as the above excerpt from the Schwinn case suggests, a standard of presumptive illegality may have failed to develop simply because its adoption has not been vigorously advocated at the trial level. In spite of their lack of acceptance, however, rebuttable presumptions offer the possibility of a more flexible approach to restraint of trade litigation, which would, in turn, more effectively carry out the important public policies that form the basis for the antitrust laws.

While there are numerous business practices which are now held to be per se violations of the antitrust statutes, ${ }^{11}$ many more practices

8. The willingness of courts to adopt such an approach in other contexts to protect important public interests is illustrated by Texas E. Transmission Corp. v. Wildlife Preserves, Inc., 48 N.J. 261, 225 A.2d 130 (1966). Normally in a condemnation proceeding the party seeking to enjoin the condemnation is required to show that the condemnor's decision was unreasonable. However, in Texas East Transmission, where a natural gas utility company had already condemned lands running through the heart of a private wildlife preserve for new pipe lines, the Suprcme Court of New Jersey placed the burden of proving the reasonableness of the route on the utility after a showing by the condemnees that (1) serious damage to the preserve would occur, and (2) an apparently reasonable alternative existed. The court insinuated that the public's interest in preserving wilderness tracts raised a presumption of unreasonableness against the utility's proposed pipe site. 48 N.J. at 264, 225 A.2d at 135.

9. One need go no further than the labels which have been attached to the rules for evidence of the court's preoccupation with the substantive content of the rules: The per se rule, though it is seldom spoken of as such, could just as well be termed an irrebuttable presumption, the "rule of reason" being but a term for the more normal allocation of the burden of proof.

10. See notes 53-65 infra and accompanying text.

11. See, e.g., Timken Roller Bearing Co. v. United States, 341 U.S. 593 (1951) (horizontal territorial divisions); Fashion Originators' Guild v. FTC, 312 U.S. 457 (1941) (group boycotts); United States v. Socony-Vacuum Oil Co., 310 U.S. 150 (1940) (price-fixing arrangements); Intcrnational Business Machs. Corp. v. United States, 298 U.S. 131 (1936) (tie-ins). 
have not yet been labeled "per se illegal" either because they are new and little data concerning them is available, or because after careful analysis reasonable-minded scholars and judges have not agreed that their overall effect is always inherently harmful. ${ }^{12}$ Often, most of the factual material with regard to the latter practices, and in particular the reasons for their implementation, is solely within the possession of the defendants. Thus, in suits in which these business practices are involved, a procedure whereby the plaintiff is required to convince judges that there has been an unreasonable restraint of trade may work an unfairness to the party bringing the suit and may seriously harm the area of commercial activity involved. A system which permits a plaintiff to rely upon a rebuttable presumption of illegality in those situations-for example, in which most of the factual material determinative of the reasonableness of an activity is in the hands of the defendant-would constitute an eminently fair method of allocating burdens of proof. On the other hand, from the antitrust defendant's point of view, particular factual settings seem so clearly to create valid exceptions to per se prohibitions-for example, tie-in arrangements used by a fledgling company in marketing a new and risky product ${ }^{13}$ - that permitting the defendant in such a situation to introduce evidence to overcome a rebuttable persumption against him rather than conclusively presuming his conduct to be illegal might add a much-needed spur to competition in many commercial fields. ${ }^{14}$

This Note will first summarize the present approach to the allocation of the burden of proof in restraint of trade cases and the state of the law with respect to rebuttable presumptions. Next considered will be two areas of antitrust litigation-that arising under section 2 of the anti-monopolization provision of the Sherman Act, and that under the Robinson-Patman Act-in which "rebuttable presumptions" have gained limited support. Finally, four specific restraint of trade situations under section 1 of the Sherman Act will be examined to demonstrate how the development of a rebuttable presumption in

12. E.g., United States v. Grinnell Corp., 384 U.S. 563 (1966) (acquisition by one company of another in the same line of business); Tampa Elec. Co. v. Nashville Coal Co., 365 U.S. 320 (1961) (total requirements contracts); Standard Fashion Co. v. Magrane-Houston Co., 258 U.S. 346 (1922) (partial vertical integration through exclusive dealing arrangements).

13. See notes $120-25$ infra and accompanying text.

14. "The Supreme Court shows a growing determination in its antitrust decisions to convert laws designed to promote competition into laws which regulate or hamper the competitive process." Bowman, Restraint of Trade by the Supreme Court: The Utah Pie Case, 77 YalE L.J. 70 (1967). 
each situation would lead to more equitable results.

\section{The "Rule of Reason": Present Alternatives}

Both the Sherman Act and later antitrust statutes were popular reactions to the ruthless display of naked self-interest that characterized the actions of many of America's entrepreneuers and industrialists in the latter half of the nineteenth century.$^{15}$ Most Americans had early accepted the tenets of Adam Smith's laissez-faire philosophy, particularly its emphasis on unbridled competition as the necessary conditon for the fullest development of the nation's economic potential. ${ }^{16}$ Therefore, any business practice which diminished industrial competition, whether in the form of the state-imposed monopolies of the eighteenth century or the post-civil war attempts by private businessmen to garner monopoly profits for themselves by agreements not to compete, was viewed as antithetical to the basic American preference for unfettered trade. The language of the Sherman Act reveals an intent to proscribe all activities which would restrain competition. ${ }^{17}$ The Supreme Court originally interpreted the Act quite literally, namely, that all restraints on trade were forbidden. ${ }^{18}$ However, the Court soon retreated from that position and accepted the view that Congress had outlawed only those business practices which placed an unreasonable restraint on competition within a particular but substantial geographic area. ${ }^{19}$ Since the "rule of reason" was the touchstone of the burden of proof in each suit, it became the duty of a court, when adjudicating a suit involving a restraint of trade claim, to weigh the respective benefits to both the practitioners and the general public of the business practice under attack against the harm-

15. "The Sherman Act was designed to be a comprehensive charter of economic liberty aimed at preserving free and unfettered competition as the rule of trade." Northern Pac. Ry. v. United States, 356 U.S. 1, 4 (1958).

16. "[Competition] will yield the best allocation of our economic resourees, the lowest prices, the highest quality and the greatest material progress, while at the same time providing an environment conducive to the preservation of our democratic political and social institutions." Id.

17. "Throughout the history of these [antitrust] statutes it has been constantly assumed that one of their purposes was to perpetuate and preserve, for its own sake and in spite of cost, an organization of industry in small units which can effectively compete with each other." United States v. Aluminum Co. of America, 148 F.2d 416, 429 (2d Cir. 1945).

18. See note 4 supra and accompanying text.

19. The "rule of reason" was introduced into antitrust jurisprudence by Chief Justice White in Standard Oil Co. v. United States, 221 U.S. 1, 68 (1911): "Unaided by the

light of reason it is impossible to understand how the statute may in the future be enforced and the public policy which it establishes be made efficacious." 
ful effects the practice would have upon other competitors and the economic system as a whole. The practice could be condemned only after a thorough economic analysis of the volume of economic activity affected, the relevant product markets and geographic markets involved and the effects on actual and potential competitors, and after product users demonstrated that the overall effect of the challenged practice would work an unreasonable restraint upon competition within the industry.

Such an approach by the courts is necessary because many types of business activities may constitute an unreasonable restraint of trade within one given market and yet in no way lessen competition within another market..$^{20}$ For example, in an industry characterized by a large number of financially healthy raw material processors and secondary fabricators, the vertical acquisition by one of the raw material processors of a secondary fabricator might have little or no effect on the ability of the other fabricators to remain competitive. Indeed, such vertical integration is quite typical of business today and is generally permitted. However, in a situation where only a small number of major raw material processors supply a vast number of small, economically unstable secondary fabricators, acquisition by one of the material processors of a fabricator might give the acquired fabricator significant competitive advantages over non-integrated rivals. These advantages would be due to greater financial resources and the advantages of integrated operation, including the opportunity to impose a "price squeeze" on non-integrated competitors by maintaining raw material prices at high levels and finished product prices at depressed levels. ${ }^{21}$

A second example of business arrangements reasonable in one setting but not in another is that of requirements contracts, wherein one company agrees to purchase exclusively from one supplier certain materials that are essential to its operation. In circumstances where the competitors of the supplying company can easily cultivate their own channels of distribution-for example, where other purchasers with large demands are relatively abundant-a foreclosure of the

20. Experience with existing laws had taught that definition [i.e., the per se rule], being necessarily rigid, would prove embarrassing and, if rigorously applied, might involve great hardship. Methods of competition which could be unfair in one industry, under certain circumstances, might, when adopted in another industry, or even the same industry under different circumstances, be entirely unobjectionable. FTC v. Gratz, 253 U.S. 421, 436 (1920) (Brandeis, J., dissenting).

21. See, e.g., Reynolds Metal Co. v. FTC, 309 F.2d 223 (D.C. Cir. 1962). 
competing suppliers from one marketing target would probably have little adverse effect on those competitors and would clearly be within the law. ${ }^{22}$ In a sense, every purchase of goods forecloses the competitors of the company supplying the goods from that particular sale, and obviously not all such sales could be called unreasonable. ${ }^{23} \mathrm{On}$ the other hand, where the requirements contract accounts for such a large percentage of the available market, and especially where such a contract is imposed by a dominant seller upon a weak purchaser, the foreclosure could quite rightly be viewed as an unreasonable restraint on trade. ${ }^{24}$

The "rule of reason" is also warranted with respect to those new modes of commercial enterprise as to which information regarding the overall impact on the industrial sector affected is still insufficient for the courts to proscribe the practices out of hand. For example, in recent years a large number of America's major corporations have sought to diversify their interests by acquiring companies operating in fields other than that of the parent company. ${ }^{25}$ Although such acquisitions are neither horizontal nor vertical mergers, it has been asserted $^{26}$ that they may still threaten competition within the product industry in which the newly-acquired company operates by making available to that company the vast financial resources and bargaining power possessed by the conglomeration as a whole. Such cases as FTC v. Consolidated Foods Corp., ${ }^{27}$ in which the acquisition by a major processed-food retailer of a dehydrated garlic and onion company was held illegal because the retailer was thereby in a position to compel its supplying food processors to make reciprocal purchases of the garlic and onion products for their own processing, demon-

22. See C. Kaysen \& D. Turner, Antitrust Policy 242 (1959).

23. See Report of the Attorney General's Nat’l Comm. to StUdy the ANTItrust LAWS 146-47 (1955).

24. See FTC v. Brown Shoe Co., 384 U.S. 316 (1966); cf. Tampa Elec. Co. v. Nashville Coal Co., 365 U.S. 320 (1961).

25. See, e.g., Loescher, Geographical Market Extension Acquisitions, in Hearings on Economic Concentration, Part II, Mergers and Other Factors Affecting Industry Concentration, Before the Subcomm. on Antitrust and Monopoly of the Senate Comm. on the Judiciary, 89th Cong., Ist Sess., at 830-40 (1965); Edwards, Conglomerate Bigness as a Source of Power, in Business Concentration and Price Policy 239 (1955).

26. See Mueller, Mergers Among Large Firms, in Hearings on Economic Concentration, Part II, Mergers and Other Factors Affecting Industry Concentration, Before the Subcomm. on Antitrust and Monopoly of the Senate Comm. on the Judiciary, 89th Cong., 1st Sess., at 515-20 (1965).

27. 380 U.S. 592 (1965). 
strate the general awareness of courts that situations involving conglomerate mergers may result in unreasonable restraints on trade..$^{28}$ At present, however, because some business motives underlying such acquisitions-particularly the need for corporations to diversify in order to free themselves from cyclical patterns of stagnation and growth and from an over-dependence upon a product which could be made obsolete by advancing technology_are obviously legitimate business concerns, such multi-industry aggregations have generally not been attacked as violative of the antitrust laws.

It is evident that the economic situations described above require the courts to maintain the "rule of reason" as an important tool in the adjudication of restraint of trade cases. However, not long after the initiation of litigation under the antitrust statutes, courts began to recognize that certain business practices were such patently unreasonable restrictions upon industrial competition that continual detailed analyses of the full economic effects of the practices within the particular factual setting involved were unnecessary. Thus, a second aspect of the problem of burden of proof in restraint of trade litigation developed.

\section{The Per Se Rule}

Significantly, the per se rule was not developed because the Supreme Court deemed itself able to recognize on first scrutiny that certain types of conduct had no other purpose and effect than to restrain competition; rather, the rule was established with regard to a particular business practice after a number of investigations regarding that practice consistently resulted in the conclusion that such conduct held no benefits for the public or the industry as a whole but instead tended to give the practitioner an undue competitive edge over its rivals..$^{29}$ For example, the decision in Board of Trade $v$. United States $^{30}$ seemed for a time to imply that certain forms of limited price-fixing would be permitted. ${ }^{31}$ However, in United States $v$. Trenton Potteries Co. ${ }^{32}$ which involved price-fixing by companies that controlled 82 percent of the vitreous pottery business in the

28. Cf. FTC v. Proctor \& Gamble Co., 386 U.S. 568 (1967).

29. Cf. Van Cise, Understanding the Antitrust Laws $69-81$ (1966); Note, Section

Two of the Sherman Act-Is a Per Se Test Feasible?, 50 Iowa L. Rev. 1196, 1199-200 (1965).

30. 246 U.S. 231 (1918).

31. But see text accompanying note 41 infra.

32. 273 U.S. 392 (1927). 
country, Justice Stone articulated for the majority of the Supreme Court the underlying philosophy of a new approach:

Agreements which create such potential [monopoly] power may well be held to be in themselves unreasonable or unlawful restraints, without the necessity of minute inquiry whether a particular price is reasonable or unreasonable . . . and without placing on the government . . . the burden of ascertaining from day to day whether . . . [the price] has become unreasonable through the mere variation of economic conditions. ${ }^{33}$

In 1940 the decision in United States v. Socony-Vacuum Oil Co. ${ }^{34}$ made the assumption in Trenton Potteries explicit:

Under the Sherman Act a combination formed for the purpose and with the effect of raising, depressing, fixing, pegging, or stabilizing the price of a commodity in interstate or foreign commerce is illegal per se..$^{35}$

Since Socony-Vacuum, the per se doctrine has been extended to prohibit a number of other business practices deemed to have as their purpose and effect the imposition of unreasonable restraints upon trade. The per se category of antitrust violations consists of:

agreements or practices which because of their pernicious effect on competition and lack of any redeeming virtue are conclusively presumed to be unreasonable and therefore illegal without elaborate inquiry as to the precise harm they have caused or the business excuse for their use. ${ }^{36}$

Such practices as tying arrangements, ${ }^{37}$ horizontal division of markets, ${ }^{38}$ group boycotts, ${ }^{39}$ and vertically imposed territorial limitations on resale ${ }^{40}$ have all been brought within the strictures of the rule.

The per se rule, however, is not invoked immediately upon the plaintiff's alleging acts by the defendant which traditionally would fit within one of the areas absolutely proscribed. The plaintiff must first demonstrate that the practice actually is within the bounds of a category of activities to which the per se rule applies. To decide this question the "rule of reason" itself is utilized, and the pertinent facts surrounding the practice, including the defendant's purpose and in-

33. Id. at 397-98 (emphasis added).

34. 310 U.S. 150 (emphasis added).

35. Id. at 223.

36. Northern Pac. Ry. v. United States, 356 U.S. 1, 5 (1958).

37. See, e.g., id.; International Salt Co. v. United States, 332 U.S. 392 (1947).

38. See, e.g., United States v. Sealy, Inc., 388 U.S. 350 (1967); United States v. American Smelting \& Ref. Co., 182 F. Supp. 834 (S.D.N.Y. 1960).

39. See, e.g., United States v. General Motors Corp., 384 U.S. 127 (1966); Radiant Burners, Inc. v. Peoples Gas Light \& Coke Co., 364 U.S. 656 (1961); Klor's, Inc. v. BroadwayHale Stores, Inc., 359 U.S. 207 (1959).

40. See, e.g., United States v. Arnold, Schwinn \& Co., 388 U.S. 365 (1967). 
tentions, are scrutinized. If this examination results in a finding that the challenged activity is indeed within one of the categories deemed per se illegal, the plaintiff's burden is satisfied. Thus, although the practice attacked in Board of Trade v. United States did "fix" prices in the sense that commodities buyers who made their purchases after the cessation of the regular trading day were all required to pay the same price-namely, the closing exchange price for that day-the exchange rule in no way "set" the actual price itself. " Examined in the light of the "rule of reason," the exchange rule was not such an arrangement as came within the traditional concept of "pricefixing," 42 but rather was merely a means for ensuring an orderly market in the commodities.

Analyzing the per se rule from an evidentiary point of view, it can be seen as nothing more than a judicial formulation of a peculiar kind of irrebuttable presumption. Once the plaintiff has established by evidence that the defendant's actions fit within a particular pattern of conduct, the presumption that that conduct is an unreasonable restraint on trade becomes controlling, evidence in rebuttal becomes immaterial, and a judgment for the plaintiff must be rendered. ${ }^{43}$ Beyond doubt the rule is valuable in saving the courts time and in protecting the public interest from anticompetitve activities clearly without any "honestly industrial" purpose. However, because of the powerful judgment-rendering effect the per se rule possesses, the courts are unwilling to release such a potent weapon on behalf of the plaintiff except when, beyond any doubt, the activity challenged merits such an approach. ${ }^{44}$ This may account for the decision of some

\footnotetext{
41. The Court stated:

[The Government] made no attempt to show that the rule was designed to or that it had the effect of limiting the amount of grain shipped to Chicago; or of retarding or accelerating shipments; or of raising or depressing prices; or of discriminating against any part of the public; or that it resulted in hardship to anyone. 246 U.S. 231, 238 (1918).
}

42. See also Judge Medina's opinion in Unitcd States v. Morgan, 118 F. Supp. 621 (S.D.N.Y. 1953), a case in which the Government had contended that an "illegal per se" pricefixing arrangement had been created by contractual arrangements obligating the members of an investment banking syndicate to adhere to prescribed prices in marketing securitics which the syndicate was organized to distribute. Judge Medina stated, "I can find nothing in any of these cases which would permit me to conclude that the rule of reason has been abandoned or discarded." Id. at 689. Applying the "rule of reason," the court determined that the agreements were not anti-competitive either in purpose or effect.

43. The rule differs from other irrebuttable presumptions only in that it involves a mixed conclusion of law and fact-that is, it involves both a factual inference that a restraint of trade has occurred and a conclusion of law that the restraint was unreasonable.

44. See Von Kalinowski, The Per Se Doctrine-An Emerging Philosophy of Antitrust Law, 
courts not to use the per se rule in certain circumstances although the defendant's conduct clearly has anticompetitive effects, ${ }^{45}$ thus throwing back on the plaintiff the full burden of proving that the conduct constitutes an unreasonable restraint of trade.

\section{Rebuttable Presumptions: A Third Alternative}

Legal presumptions ${ }^{46}$ are inferences of fact that courts will recognize to exist when the facts necessary to give rise to the presumption have been proven to exist. ${ }^{47}$ The law is replete with presumptions-for example, a man whose absence is unexplained for seven years is dead, a child under the age of seven is incapable of forming the mens rea necessary for a conviction of murder, and a person found dead did not commit suicide. The use of any particular presumption is based on one or more of the following reasons:8 (1) probability-that is, experience has demonstrated that if fact $A$ is true it is highly probable that inference $B$ is also true; ${ }^{49}(2)$ procedural convenience-for example, it saves time to presume that a criminal defendant is sane; ${ }^{50}(3)$ fairness in allocating the burden of producing evidence upon the party who has superior access to it; ${ }^{1}$ and (4) notions of social and economic policy, usually implicit rather than expressed. ${ }^{52}$

The key problem with respect to presumptions that has kept the courts and commentators locked in furious debate is the question of how much weight a presumption should be said to possess. Some

II U.C.L.A.L. REv. 569 (1964), in which the author grimly warns of the danger in an overzealous application of the per se rule.

45. See, e.g., White Motor Co. v. United States, 372 U.S. 253 (1963).

46. See generally 9 J. WIGMORE, TREaTISE ON EvideNCE $\$ 2483-98$ (1940); C. MCCORMICK, supra note 6, $\$ 306-22$; Gausewitz, Presumptions in a One-Rule World, 5 VAND. L. REV. 324 (1952); Morgan, How to Approach Burden of Proof and Presumptions, 25 RockY MT. L. Rev. 34 (1952); Morgan, Some Observations Concerning Presumptions, 44 HaRv. L. Rev. 906 (1931).

47. [A] presumption is a standardized practice, under which certain oft-recurring fact groupings are held to call for uniform treatment whenever they occur, with respect to their effect as proof to support issucs. McCormick, Charges on Presumptions and Burden of Proof, 5 N.C.L. REv. 291, 295 (1927).

48. See C. MCCoRmick, supra note 6, § 309; Morgan, Presumptions, 12 Wash. L. Rev. 255, 257 (1937).

49. See, e.g., Franklin Life Ins. Co. v. Brantley, 231 Ala. 554, 165 So. 834 (1936); Price v. Price, 156 Pa. 617, 27 A. 291 (1893).

50. See, e.g., Davis v. United Statcs, 160 U.S. 469 (1895).

51. See, e.g., Young v. Masci, 289 U.S. 253 (1933); Bowman v. Vandiver, 243 Ky. 139, 47 S.W.2d 947 (1932).

52. See, e.g., Oklahoma Ry. v. Guthrie, 175 Okla. 40, 52 P.2d 18 (1935); Guyer v. Synder, 133 Md. 19, 104 A. 116 (1918). 
presumptions present no problem because they are irrebuttable; ${ }^{53}$ the inference at the heart of the presumption will stand as proven in spite of all the evidence that might have been introduced to the contrary..$^{54}$ It would appear that the per se rules developed in antitrust law are of this variety, although they are not usually characterized as such. Thus, when the Government shows in its case that a number of competing companies have willfully agreed to establish the price at which they will sell a particular item, the court will hold, in effect, that from the fact of price-fixing there arises an inference that an unreasonable restraint of trade has been created ${ }^{55}$ which dictates the outcome of the case, notwithstanding benefits to the public or de minimis harm to competition which the defendants might believe they could demonstrate. However, if a presumption is rebuttable, the question becomes what measure of evidence to the contrary need be presented to rebut the inference that it raises. The most authoritative commentators in the field of evidence have never agreed on this point.

Professors Thayer ${ }^{56}$ and Wigmore ${ }^{57}$ have presented the view that a permissive presumption of law should have no substantive evidentiary value..$^{58}$ In other words, the presumption has only procedural consequences; ${ }^{59}$ it gets the case past the judge to the jury, and when it has operated as such it is functus officio ${ }^{60}$ Thus, when evidence is introduced to rebut the presumption-however weak the evidence may be-the presumption is overcome and destroyed ${ }^{61}$ Quite aptly this doctrine is known as the "bursting bubble" theory. Professor Morgan, on the other hand, asserted that the presumption does have substantive evidentiary value, ${ }^{22}$ moreover, he argued that the effect

53. Professor McCormick refers to such presumptions as "mandatory presumptions," while non-mandatory presumptions are termed "permissive." McCormick, supra note 47, at 297.

54. The presumption of death from seven years' absence unheard from is usually considered mandatory. C. MCCORMICK, CASES AND MATER1als ON THE LAW OF EvideNCE 609 n.12 (3d ed. 1956). See, e.g., Simpson v. Simpson, 162 Va. 621 , 175 S.E. 320 (1934).

55. This inference is a conclusion of both fact and law. See note 43 supra.

56. J. Thayer, A Preliminary Treatise on Evidence at the Common Law 336 (1898),

57. J. WIGMORE, supra note 46, $\$$ 2490-91.

58. Ryan v. Metropolitan Life Ins. Co., 206 Minn. 562, 289 N.W. 557 (1939); Wright v.

Bridges, 16 Tenn. App. 576, 65 S.W.2d 265 (1933).

59. See Equitable Life Assurance Soc'y v. Sieg, 53 F.2d 318 (6th Cir. 1931).

60. Such a presumption has been likened to a male bee; after functioning, it disappears. Wyckoff v. Mutual Life Ins. Co. of N.Y., 173 Ore. 592, 147 P.2d 227 (1944).

61. There has been much criticism of this view. See, e.g., Cleary, Presuming and Pleadling: An Essay on Juristic Immaturity, 12 STAN. L. REv. 5, 18 (1959).

62. Morgan \& Maguire, Looking Backward and Forward at Evidence, 50 HARv. L. REv. 
of the presumption was actually to shift the burden of persuasion $^{63}$ - that is, once the presumption was raised it stood until sufficient evidence was presented to make it more likely than not that the presumptive inference was not true. ${ }^{64}$ Although the language in many cases is often contradictory or unclear, probably the most commonly accepted view is that of a modified Morgan approach, namely, that the presumption has substantive evidentiary value but it does not have the effect of shifting the burden of persuasion to the party against whom the presumption operates. ${ }^{65}$

The burden of proof in antitrust litigation is determined by either the "rule of reason" or the per se rule. Both rules are also substantive rules of law that determine whether evidence introduced by the plaintiff should be held to require the inference that the defendant's conduct is unreasonable. Therefore, if rebuttable presumptions are to be similarly utilized in antitrust litigation, Professor Morgan's theory-that the presumption itself may stand as evidence from which the trier of fact can infer the illegality of defendant's conduct, in spite of contrary evidence introduced to rebut it-would be convincing. The central question in an antitrust suit cannot be answered by basic sensory impressions, as the question "Did $X$ strike $Y$ ?" could

909 (1937). For cases adopting a view similar to that of Professor Morgan, see Arkimo Lumber Co. v. Luckett, 201 Ark. 140, 143 S.W.2d 1107 (1940); Mitchell v. Industrial Comm'n of Ohio, 135 Ohio St. 110, 19 N.E.2d 769 (1939); Provident Life \& Accident Ins. Co. v. Prieto, 169 Tenn. 124, 83 S.W.2d 251 (1935); Worth v. Worth, 48 Wyo. 441, 49 P.2d 649 (1935).

63. The "burden of persuasion" is synomyous with the "burden of proof." See Rule 1, UNIFORM RULES OF EVIDENCE (1953).

64. Professor Morgan believed that there should be a general rule "that the sole effect of every presumption shall be to place upon the opponent the burden of persuading the trier of fact of the nonexistence of the presumed fact." Morgan \& Maguire, supra note 62, at 913 .

Rule 14 of the UNIFORM RULES OF EvidENCE (1953), apparently a compromise between the Wigmore and Morgan views, provides as follows:

Rule 14. Effect of Presumptions.

Subject to Rule 16, and except for presumptions which are conclusive or irrebuttable under the rules of law from which they arise, (a) if the facts from which the presumption is derived have any probative value as evidence of the existence of the presumed fact, the presumption continues to exist and the burden of establishing the non-existence of the presumed fact is upon the party against whom the presumption operates, (b) if the facts from which the presumption arises have no probative value as evidence of the presumed fact, the presumption does not exist when evidence is introduced which would support a finding of the non-existence of the presumed fact, and the fact which would be otherwise presumed shall be determined from the evidence exactly as if no presumption was or had ever been involved.

See In re Lundvall's Estate, 242 Iowa 430, 46 N.W.2d 535 (1951).

65. See, e.g., Grieger v. Vega, 153 Tex. 486, 271 S.W.2d 85 (1954); Nichols v. Winfrey, 90 Mo. 403, 2 S.W. 305 (1886). 
be by the direct observation of an eyewitness; nor can it be resolved by a scientific experiment. Rather, the question "Does the particular action challenged create an unreasonable restraint of trade?" calls for a factual determination of a conclusory, interpretive nature, based on a complex analysis of numerous complicated factors. As a result, in practically every situation the defendant could present some evidence that would leave the issue in doubt. Therefore, if the ThayerWigmore "bursting-bubble" theory, in which the presumption has no substantive value, were used, in every case the presumption would readily and easily be extinguished.

If rebuttable presumptions are to be used in antitrust litigation at all, the use of full Morgan-type presumptions-that is, presumptions that shift the burden of persuasion to the party against whom the presumption operates-seems particularly appropriate in view of the mixed conclusion of law and fact which the inference of an unreasonable restraint of trade entails. The use of such presumptions in the antitrust context can be justified on at least three grounds. First, in many situations the facts necessary to prove an antitrust violation are within the sole possession of the defendant. For example, a steel purchaser would have no access to information needed to determine whether a price increase by a major steel producer matched by similar increases by other steel producers is a result of "conscious parallelism," gally, by each producer but with the action of competitors in mind-or the result of illegal agreements made by the companies to fix the price of the product throughout the industry. ${ }^{67}$ Requiring the steel producers in such a situation to rebut a presumption of illegality arising from the parallel price increases by presenting evidence demonstrating that their decisions were, in fact, independently arrived at, would be a fair means for removing the hurdle confronting the plaintiff attempting to meet his burden of proof.

A second reason for adopting an intermediate position is to present the courts with a tool that will better ensure competition in certain areas which have not yet come within the ambit of the per se rule. The need for such a device has developed because of the greatly

66. For an analysis of the problem of "conscious parallelism" and "price leadership" in the steel industry, see W. AdAmS, The Structure of AMERICAN INDUSTRY 148 et seq. (1954).

67. For an excellent discussion of this problem, see Turner, The Definition of Agreement Under the Sherman Act: Conscious Parallelism and Refiusals to Deal, 75 HARv. L. Rev. 655 (1962). 
increased centralization of economic power around a relatively small number of corporate entities that has occurred in recent years. When this is viewed against a background of rapidly accelerating interdependence of all facets of American society, the vast potential harm that a small group of selfish businessmen could render becomes frightfully evident. Thus a public policy against harmful restraints of trade even stronger than that currently maintained, embodied in the form of rebuttable presumptions, could be developed and sustained by the courts.

Third, because any rule of law, including those governing the issue of burden of proof in antitrust cases, must by its nature be general, one can hardly expect it to deal adequately with every factual situation that may arise. ${ }^{68}$ Undoubtedly, situations exist where precedent seemingly demands implementation of the per se rule, while the peculiar facts of the case would ensure that utilization of that rule actually hinders rather than promotes competition. ${ }^{69}$ Permitting a court in such a situation to choose the intermediate position of a rebuttable presumption would provide the flexibility required without throwing the burden of persuasion back onto the plaintiff.

Despite the availability of such a potent and flexible tool, the courts have nevertheless decided to choose only between the per se rule and the "rule of reason." That other alternatives are feasible is shown by the fact that a number of scholars and judges have already proposed the use of rebuttable presumptions in the limited area of monopoly control ${ }^{70}$ and that the very language of the RobinsonPatman Act requires such an approach for cases involving selling price differentials. ${ }^{71}$ The role of the rebuttable presumption in these two areas shall now be briefly considered, followed by illustrations in the broad area of restraint of trade litigation of the usefulness of such a presumption.

68. See generally Elman, "Petrified Opinions" and Competitive Realities, 66 Colum. L. REV. 625 (1966), where the author states:

It should be plain why there is a real danger of the abuse of the per se principle by those pre-disposed to offer mechanical or dogmatic solutions to legal problems. In every antitrust case there are two routes to a finding of illegality: critically analyzing the competitive effects and possible justifications of the challenged practice; or subsuming it under one of the per se rules. The latter route is naturally the more tempting; it is easier to classify a practice in a forbidden category than to demonstrate from the ground up, as it were, why it is against public policy and should be forbidden. $I d$. at 627 .

69. See notes 104-08 infra and accompanying text.

70. See notes $76-87$ infra and accompanying text.

71. See notes $88-91$ infra. 
Monopolies, Selling Price Differentials, and the Rebuttable Presumption

Section 2 of the Sherman Act declares it illegal for anyone to monopolize, attempt to monopolize, or conspire to monopolize any part of interstate and foreign commerce. Thus, the Act literally prohibits conduct, not the occurence of a condition that results from such conduct. However, when one successfully "monopolizes," he causes a particular factual occurrence, that of the acquisition of "monopoly control," to come about. For this reason, many suits brought under section 2 attempt to demonstrate that the defendant's past conduct was "monopolizing" by proving that the defendant now wields "monopoly control."

The acquisition of monopoly control over a product, however, is an activity that may or may not violate the antitrust laws, depending upon the factual setting in which it occurs. It is quite possible for there to be only one producer of an item within a significant market area because no one else has sought to produce the same item. It would be preposterous to suggest that such a monopoly situation is a kind that the Sherman Act prohibits. There are also situations, as Judge Learned Hand explained in the landmark case, United States v. Aluminum Co. of America, ${ }^{72}$ in which a company might legitimately acquire monopoly control over a product, even in the face of active competition, because of that company's "superior skill, foresight, and industry." 73 The courts recognize that a monopoly thus "thrust upon"74 a company is a form of monopoly which the Sherman Act does not forbid. Because a company made the subject of a complaint under section 2 of the Sherman Act may have thcse legitimate defenses available, a per se approach to monopoly control is impossible.

Nevertheless, evidence of monopoly control over a product continues to be an essential element in section 2 actions. A determination that a company has acquired monopoly control over a product is the result of arduous analysis by the trier of fact after mountains of conflicting evidence have been presented by the two parties to the suit. Key indications that a company has acquired monopoly control are that the company has been able to compel competitors to follow

72. 148 F.2d 416 (2d Cir. 1945).

73. Id. at 430 .

74. Id. at 429 . 
its lead in price and marketing policies, and that the company has been able to significantly raise its prices without suffering losses in sales. However, probably the most common indication of monopoly power which the courts look for is a company's ability to exclude anyone else from entering the relevant market, as reflected by the company's share of the sales of the product under consideration. ${ }^{75}$ And it is with reference to this indicator that suggestions have been forthcoming that a rebuttable presumption of illegality be utilized.

Such a suggestion formed the basis for the district court opinion in United States $v$. Grinnell Co. ${ }^{76}$ a case in which the defendant was shown to have acquired control over eighty-seven percent of the relevant product market. ${ }^{77}$ According to Judge Wyzanski:

[m]ost of the cognoscenti have expected that a day would come when the Supreme Court would announce that where one or more persons acting jointly had acquired so clear a dominance in a market as to have the power to exclude competition therefrom, there was a rebuttable presumption that such power had becn criminally acquired and was a monopolizing punishable under $\S 2$ .... [S]uch a rebuttable presumption rests on the by-now dozens of court records which make it quite clear that it is the highly exceptional case, a rara avis more often found in academic groves than in the thickets of business, where monopoly power was thrust upon an enterprise $\ldots . .^{78}$

In Judge Wyzanski's opinion, both the burden of going forward and the burden of persuasion are to shift in such a situation. ${ }^{79}$ According to Judge Wyzanski:

[o]nce the Government has borne the burden of proving what is the relevant market and how predominant a share of that market defendant has, it follows that there are rebuttable presumptions that defendant has monopoly power and has monopolized in violation of section 2. The Government need not prove, and in a well-conducted trial ought not to be allowed to consume time in needlessly proving, defendant's predatory tactics, if any, or defendant's pricing, or production, or selling, or leasing, or marketing, or financial policies

75. See United States v. Grinnell Corp., 384 U.S. 563, 571 (1966), where the Court stated: "In United States v. Du Pont \& Co., 351 U.S. 377, 391, we defined monopoly power as "the power to contrcl prices or exclude competition.' The existence of such power ordinarily may be inferred from the predominant share of the market."

76. 236 F. Supp. 244 (D.R.I. 1964).

77. Although it has been asserted that Judge Hand's opinion in the Aluminum Co. case rested sclely on the view that the defendant's control of $90 \%$ of the virgin aluminum ingct market created a presumption that Alcoa was an illegal monopcly, Bcwman, Toward Less Monopoly, 101 U. PA. L. Rev. 577, 583 (1953), Judge Hand's thcrough analysis of Alcca's aacquisitions and other business practices that enabled it to maintain its dominant position rebut such a supposition. See Note, supra note 29, at 1206 n.75.

78. 236 F. Supp. at 248.

79. Id. 
while in this predominate role. If defendant wishes to go forward, it is free to do so and to maintain the burden of showing that its eminence is traceable to such highly respectable causes as superiority in means and methods which are "honestly industrial. . . ."

However, on appeal the Supreme Court stated that the consideration of a rebuttable. presumption established solely by demonstration of the firms' -present 'market share was unnecessary since there was abundant evidence to show that Grinnell's monopoly power was illegally acquired..$^{81}$

Notwithstanding the disposition of the Grinnell case on appeal, a number of cases and commentators have suggested a similar approach to that proposed by Judge Wyzanski, asserting that when it is shown that the defendant controls a particular percentage ${ }^{82}$ of the product considered, then the rebuttable presumption should arise that such vast control was the result of illegal aggrandizement, placing upon the defendant the burden of justifying the control which it possesses. One such suggestion is that a presumption of illegality should be applied against firms producing more than ten to fifteen percent of a product for a given market in which there are numerous competitors. This approach, it is argued, would eliminate a major gap that has existed in antitrust enforcement-applicability to nonconspiracy oligopolies. ${ }^{83}$ A slightly different proposal, ${ }^{84}$ while not setting out any percentage limitations, asserts that where a group of oligopolists working in concert, either collusively or through some form of "price leadership," or a dominant single firm, is shown to possess unreasonable "market power," ${ }_{85}$ a presumption should arise that such power was acquired and is now being maintained in violation of the Sherman Act. ${ }^{86}$ It would then fall to the defendants to show that their

80. Id. For a thorough critique of the Wyzanski rule, see Note, supra note 29.

81. United States v. Grinnell Corp., 384 U.S. 563, 576 n.7 (1966).

82. See, e.g., United States v. Aluminum Co. of America, 148 F.2d 416, 424 (2d Cir. 1945), where the court stated: "That percentage [over 90\%] is enough to constitute a monopoly; it is doubtful whether sixty or sixty-four percent would be enough; and certainly thirty-three percent is not enough."

83. Bowman, supra note 77 , at 589.

84. C. KAYSEN \& D. TURNeR, supra note 22 , at $111-13$.

85. A firm possesses market power when it can behave persistently in a manner different from the behavior that a competitive market would enforce on a firm facing otherwise similar cost and demand conditions. $I d$. at 75 .

86. The enforcing agency would be required to demonstrate that the firm (or firms) under examination possessed market power by:

(1) delimiting the market in which the firms operate and by describing the character- 
market power was reasonable, due to economies of scale, patents, or introduction of new products, processes, or techniques. ${ }^{87}$

One area of antitrust law which has given explicit recognition, in the form of legislation, to the use of rebuttable presumptions is the Robinson-Patman Act's ${ }^{88}$ prohibition against selling-price differentials. A major exception to the presumption arises where the difference is justified by lower handling costs resulting from a particular method of sale. Specifically, a vendor cannot sell his goods to a largevolume purchaser at a cost per unit less than the cost per unit which a small-volume purchaser would pay unless actual economies-for example, those resulting from less handling or packaging per basic unit-accrue when the product is sold in great quantities.89 If the vendor does sell his basic units at more than one price, he must bear the burden of proving, in any suit brought against him by a smallvolume purchaser, that actual economies did occur in selling at large volume..$^{90}$ Thus, where the plaintiff-purchaser shows that the vendor has offered goods to a large-volume competitor at a price lower than that offered to the plaintiff, a presumption arises that this selling

istics of the demand which they meet;

(2) establishing the average market share of the group and the individual firms over the period under study, and noting any trends in market shares;

(3) examining the conditions of entry into the market, the conditions of expansion and output for firms other than the respondents, and the actual history of entry and nonentry;

(4) when a group of firms is involved, showing that the market is such that they do in fact act jointly to exercise market power, rather than in such a way as to limit each other's power;

(5) testing the conclusions of (1) through (4) against the relevant dimensions of performance, price-cost margins, in the aggregate and for separate products and submarkets; output-capacity relations; capacity-demand relations; technical efficiency. Id. at 112 .

87. Id. at 113 .

88. 15 U.S.C. $\$ 13$ (1970). See generally, W. Patman, Complete Guide to the Robinson-Patman act (1963); F. Rowe, Price Discrimination Under the RobinsonPatman Act (1962, Supp. 1964); H. Taggart, Price Justification (1959).

89. The exception reads:

Provided, That nothing herein contained shall prevent differentials which make only due allowance for differences in cost of manufacture, sale, or delivery resulting from the differing methods or quantities in which such commodities are to such purchasers sold or delivered .... Robinson-Patman Act $\S 2(a), 15$ U.S.C. $\S 13(a)$ (1970).

90. Upon proof being made, at any hearing on a complaint under this section, that there has been discrimination in price or services or facilities furnished, the burden of rebutting the prima facie case thus made by showing justification shall be upon the person charged with a violation of this section. . . . Id. $\S 2(\mathrm{~b}), 15$ U.S.C. $\S 13(\mathrm{~b})$ (1970).

See also Howrey, The Robinson-Patman Act and a Prima Facie Case, 37 Geo. L.J. 541 (1949). 
price differential resulted from anti-competitive motives and conduct-for example, from pressure exerted by the large-volume purchaser-rather than from actual economies accruing from selling on a massive scale. Only if the seller can present sufficient evidence to rebut this presumption will the selling price differential be validated. ${ }^{01}$

\section{The Rebuttable Presumption in Restraint of Trade Cases: Four Il- lustrations}

The rebuttable presumption, legislatively required in certain Robinson-Patman cases, recommended by many in monopoly cases, but largely ignored by the courts in handling most antitrust cases, could also be utilized to provide efficiency in administration and fairness in the area of restraint of trade litigation. This section will consider four restraint of trade situations as illustrations: product certification, vertically imposed territorial restrictions, maximum resale price-setting, and tie-ins.

Product Certification. Product certification-the labeling by a trade association or other group of a product to show that it meets certain quality standards-plays a major role in modern American industry ${ }^{92}$ The importance of certification has increased as money from the federal government has become available to finance projects once left to private development. For example, in order for federal funds for low-income housing to be procured, the developers must meet specific standards established by the particular federal agency involved with the program. In almost every instance the standards regarding materials or procedures to be used in an area, whether selected by trade associations or the federal government, reflect the

91. Emphasizing the elements of fairness and public policy, the Second Circuit Court of Appeals, in Samuel H. Moss, Inc. v. FTC, 148 F.2d 378, cert. denied, 326 U.S. 734 (1945), stated:

It is true that $\S 2$ (a) makes price discrimination unlawful only in case it lessens, or tends to prevent, competition with the merchant who engages in the practice; and that no doubt means that the lower price must prevent, or tend to prevent, competitors from taking business away from the merchant which they might have got, had the merchant not lowered his price below what he was charging elsewhere. But that is often hard to prove; the accuser must show that there were competitors whom the higher of the two prices would, or might, not have defeated, but who could not meet the lower. Hence Congress adopted the common device in such cases of shifting the burden of proof to anyone who sets two prices, and who probably knows why he has done so, and what has been the result. Id. at 379 .

Compare FTC v. Borden Co., 383 U.S. 637 (1966), with Quaker Oats Co., 66 F.T.C. 1131 (1964), and Universal-Rundle Corp., 65 F.T.C. 924 (1964).

92. See generally Bodner, Antitrust Restrictions on Trade Association Membership and Participation, 54 A.B.A.J. 27 (1968). 
materials or procedures being used by most of the private concerns working in that area. For example, the cornmercial standards approved and published by the Department of Commerce are not the results of independent tests made by the Department; rather, they reflect the consensus of the industry. Generally, the Department will not designate a standard unless it is approved by at least seventy-five percent of the producers of the product ${ }^{93}$ While little antitrust litigation has arisen with respect to product certification, one fairly recent case, Structural Laminates, Inc. v. Douglas Fir Plywood Ass'n, ${ }^{94}$ demonstrates how the practice might act as a restraint on trade and how the use of a rebuttable presumption would result in a far more equitable outcome than is the case under the "rule of reason."

In 1957 Structural Laminates, Inc. constructed a mill and commenced the production of 3-ply, one-half inch sheathing construction plywood. This plywood was made of three pieces of relatively low grade veneer, each one-sixth inch thick, glued together. However, at the time the most commonly used one-half inch sheathing was made of five pieces of veneer, each one-tenth inch thick. Accordingly, the Department of Commerce had adopted Douglas Fir Plywood Commercial Standard 45, which held that only 5-ply sheathing, and not 3-ply, was acceptable for one-half inch sheathing. Companies meeting the Department's Commercial Standard could stamp their product to that effect, and sheathing without such marking was more difficult to sell and brought a lower price. The Douglas Fir Plywood Association, a trade association of over one hundred plywood manufacturers that produced eighty-two to eighty-nine percent of all soft plywood in the United States, had been instrumental in the adoption of CS 45. It had reported to the Department of Commerce that because of gluing and drying difficulties resulting from industry-wide use of roller-type dryers, 3-ply, one-half inch sheathing was not adequate for construction purposes. Nevertheless, in 1957 Structural Laminates commenced production of its 3-ply product, having conducted tests which demonstrated that the new kiln-type dryer it had installed eliminated the difficulties that had previously rendered 3ply, one-half inch sheathing unacceptable. Its sheathing was able to pass the CS 45 performance tests conducted both by Structural and an independent, reputable testing agency, prompting Structural to

93. See Structural Laminates, Inc. v. Douglas Fir Plywood Ass'n, 261 F. Supp. 154, I56 (D. Ore. 1966).

94. Id. 
press the Association for a review of CS 45 to include 3-ply, one-half inch sheathing. The Association refused, and it was not until 1963, after the Association's technical staff had run a number of separate tests on Structural's product, that CS 45 was amended to include 3ply, one-half inch sheathing. However, because of the unwillingness of purchasers to consider its product, Structural Laminates had ceased operating in 1960. Structural decided to bring suit against the Association, charging that it had unreasonably restrained trade by refusing to recommend a revision of CS 45. Despite Structural's ability to show that many of the Association's members had large inventories of one-tenth inch veneer and had therefore benefited from the refusal to alter CS 45, and that one-sixth inch veneers had been accepted in 1958 in other plywood thicknesses, it was unable to convince the Structural Laminates court that the Association's action was unreasonable. The court asserted that because the other mills did not have kiln-type dryers and lacked familiarity with the newly developed glues, it was reasonable for the Association to believe that the industry in 1958 was not ready as a whole to produce a satisfactory 3-ply, one-half inch sheathing.

It would appear that Structural, although presenting an arguable case, was unsuccessful in its suit because it was unable to satisfy its burden of proving that the Association had acted unreasonably. However, it seems clear that if CS 45 had been amended to include 3-ply one-half inch sheathing, only such sheathing that could also pass the CS 45 performance tests would have met CS 45 standards, so the fact that the other mills could not produce a 3-ply sheathing that could meet CS 45 standards should not have rendered Structural's sheathing unacceptable. Because of the great power of groups like the Douglas Fir Plywood Association to prevent competition threatened by dynamic and innovative companies, utilization of a rebuttable presumption would be quite appropriate in this situation. Upon plaintiff's showing that its product had met or surpassed the performance requirements of the applicable commercial standard, and that it had requested the Association to seek an amendment of the Standard, a rebuttable presumption should arise that the Association's failure to take the necessary action resulted from a desire to prevent the entry of a new competitive product into the industry. In practically every instance the Association itself, not the complainant, would possess the necessary information as to why the alteration had not been recommended. Further, the benefits accruing to most of the members of the Association by maintaining the status quo are obvious. Finally, 
since the commercial standards themselves are, in a real sense, restraints on trade, it would appear fair to place on the Association, in situations where that body is generally responsible for adoption of the appropriate commercial standards, the burden of proving that refusing to alter the industry standard to permit the entry of a new product or method was not unreasonable under the circumstances.

Vertically Imposed Territorial Restrictions. As far back as 1899, when the Supreme Court handed down its decision in Addyston Pipe \& Steel Co. v. United States, ${ }^{95}$ horizontal territorial restrictions-agreements by competing companies to eliminate commercial warfare between each other by restricting the marketing of each competitor to a geographically limited area-have been recognized as simply "naked restraints of trade."96 However, the problem of vertically imposed territorial restrictions-restrictive agreements between suppliers and resalers as to the territorial distribution of a given product-is far more complicated. ${ }^{97}$ One major facet of the farreaching determination by the Supreme Court in United States $v$. Arnold, Schwinn \& $\mathrm{Co}^{98}$ was that a manufacturer may limit the marketing territory of dealers handling its products on a consignment basis - that is, in a manner indistinguishable from that of agents or salesmen of the manufacturer-without running afoul of the antitrust law. An equally significant aspect of Schwinn was the Court's decision that if the manufacturer sold the product to the dealer, so that the dealer was not acting as an agent of the manufacturer but as an independent businessman with his own wares to sell, any attempt by the manufacturer to impose limits as to the geographical territory within which the dealer could resell the product would constitute a per se violation of the Sherman Act. ${ }^{99}$ This latter decision came as a mild shock to those in the antitrust field, for just four years earlier, in White Motor Co. v. United States, ${ }^{100}$ the Court had stated that evidence was insufficient to categorize such a vertically imposed re-

95. 175 U.S. 211 (1899).

96. White Motor Co. v. United States, 372 U.S. 253, 263 (1962). See also Timken Roller Bearing Co. v. United States, 341 U.S. 593 (1951).

97. See Jordan, Exclusive and Restricted Sales Areas Under the Antitrust Laws, 9 U.C.L.A.L. Rev. 111 (1962); McLaren, Territorial Restrictions, Exclusive Dealing, and Related Sales Distribution Problems Under the Antitrust Laws, 11 PRAC. LAw. 79 (no. 4, 1965); Preston, Restrictive Distribution Arrangements: Economic Analysis and Public Policy Standards, 30 LaW \& Contemp. Prob. 506 (1965).

98. 388 U.S. 365 (1967).

99. Id. at 379 .

100. 372 U.S. 253, $261-64$ (1963), rev'g 194 F. Supp. 562 (N.D. Ohio 1961). 
striction as a per se violation.

The White Motor Co. case, like Schwinn, dealt with vertically imposed territorial restrictions on the dealer's resale of a product. The district court granted summary judgment against the defendant manufacturer, adopting the Government's view ${ }^{101}$ that the restrictions were illegal per se. ${ }^{102}$ On review, the Supreme Court refused to sanction the territorial restriction scheme; however, it also refused to affirm the district court's decision and held that the applicable rule of law as to burden of proof should be designated only after a full trial had been held. Because the case was the first involving vertically imposed territorial restrictions that the Court had ever considered, it asserted that it did not

know enough of the economic and business stuff out of which these arrangements emerge to be certain. They may be too dangerous to sanction or they may be allowable protections against aggressive competitors or the only practicable means a small company has for breaking into or staying in business . . . and within the "rule of reason." We nced to know more than we do about the actual impact of these arrangements on competition to decide whether they . . . should be classified as per se violations of the Sherman Act. ${ }^{103}$

Just four years later and with little or no more experience in deciding cases involving similar vertically imposed territorial restrictions, ${ }^{104}$ the Supreme Court evidently decided that it had acquired sufficient knowledge and expertise in the area to brand such restrictions on resale by dealers as per se violations. Justice Fortas, speak-

101. Even the Government had recognized that not all the considerations relevant to the validity of a particular form of restraint could be presented by a summary proceeding. Its brief provided:

What is the importance of interbrand as opposed to intrabrand competition? . . . Will White's restrictions remain reasonable if its share of the market increases? . . . These are only a few of the issues relevant to the trial of the "reasonableness" of any particular set of territorial restrictions. Nor could one be content with a single investigation. Business conditions change. The effect of restricting competition among dealers today may be different tomorrow. Brief for the United States at 31-32, quoted in 372 U.S. 253 at 266 n.3.

102. 194 F. Supp. at 585-88.

103. 372 U.S. 253,263 (1963).

104. See United States v. Arnold, Schwinn \& Co., 388 U.S. 365 (1967) where Justice Stewart, dissenting, argued:

The Court today is unable to give any reason why, only four years later, this precedent should be overruled. Surely, we have not in this short interim accumulated sufficient new experience or insight to justify embracing a rule automatically invalidating any vertical restraints in a distribution system based on sales to wholesalers and retailers. . . . Indeed, the Court does not cite or discuss any new data that might support such a radical change. Id. at 389. 
ing for the majority in United States v. Arnold, Schwinn \& Co. ${ }^{105}$ stated that the per se rule had been applied because the specific illustrations articulated in the White Motor Co. case as possible factors relevant to a showing that a "rule of reason" approach was appropriate-namely, the existence of a small company struggling against much larger competitors or a new company attempting to break into the market-were not present. Since the restrictions operated as mere "naked" restraints imposed by one party on the alienability of property owned by another, they were, beyond question, unreasonable. ${ }^{106}$

Justice Stewart, dissenting, pointed out that the district court had explicitly followed the dictates of White Motor Co. and, after a full exploration of the effects of the Schwinn restriction plan, had decided that the ultimate effect of the defendant's policies was to enhance rather than undermine or destroy competition. "No previous antitrust decision of this Court," wrote Justice Stewart, "justifies its action." 107

Most interesting in Schwinn was the majority's use of the per se rule even though the Government itself had abandoned such an approach after the district court had rejected it. Although on appeal the Government had urged the adoption of a "standard of presumptive illegality," or a rebuttable presumption, the majority chose not to consider this "additional subtlety." As a result, the Court was left to choose either of the two extremes. Sensing instinctively that something in the Schwinn scheme smacked of illegality, but fearing that to put the Government to the full proof in such a confusing and uncharted area would probably mean that the unreasonableness of the Schwinn restrictions would not be sufficiently exposed, the Court seemingly ignored White Motor Co., and imposed an absolute rule. If a rebuttable presumption had been utilized, Schwinn would have had opportunity to present evidence, as suggested by Justice Brennan in White Motor Co., ${ }^{108}$ that might justify its restrictions. In addition,

105. Id.

106. Justice Stewart, dissenting, $i d$. at 391-92, further pointed out that even at common law, only unreasonable restrictions imposed by one party on another's right to alienate his property were illegal.

107. Id. at 388.

108. Possible justifications for such territorial restrictions which Justice Brennan delineated in his concurring opinion in White Motor Co. v. United States, 372 U.S. 253, 268-69 (1963), are the promotion of vigorous inter-brand competition fostered by the added incentive of cxclusive territory given to dealers, and the encouragement of the marketing of new and risky products by distributors due to guarantces of territorial insulation. 
if the totality of the evidence presented left the entire issue in doubt, as was quite likely to happen in an area in which courts have had practically no experience, the presumption would have stood unrebutted and the majority's instinctive dislike for the plan vindicated, with no rude jolt to the judicial nervous system as unfortunately occurred.

Maximum Resale Price-Setting. Maximum resale price-setting is a third area in which the either-or approach has brought about results which are antithetical to the goal of fostering commercial competition. Dicta in cases involving minimum price-setting ${ }^{109}$ had indicated that any schemes to fetter the purchaser-seller's freedom to fix the prices at which they would sell, by imposing either minimum price floors or maximum price ceilings, were restraints that could have no significant justification and therefore were illegal per se. Thus, Kiefer-Stewart Co. v. Seagram \& Sons, ${ }^{110}$ the first case to actually deal with maximum price-setting, held that any scheme achieving such a result was likewise absolutely forbidden." preme Court has recognized that schemes to fix maximum resale prices, by substituting the possibly erroneous judgment of a producer for the forces of the competitive market, may severely limit the ability of purchaser-sellers to survive in the market. Maximum prices may be set so low that the dealer is unable to furnish services or conveniences which consumers desire and for which they are willing to pay. In addition, the resale price may be set at such a level that only large-volume sellers can afford to offer the product, thus eliminating the competition furnished by less efficient, smaller volume dealers. ${ }^{112}$ Consequently, the Court was unwilling to require the victims of such schemes to assume the burden imposed by the "rule of reason."

However, the second, and latest, decision by the Supreme Court on maximum resale price-setting, Albrecht $v$. Herald Co. ${ }^{113}$ demonstrates that the extension of the per se doctrine into this area may have been a mistake, and that fixing the burden of proof through a rebuttable presumption of illegality may be a sounder approach.

109. United States v. Socony-Vacuum Oil Co., 310 U.S. 150, $221-24$ (1940); United States v. Trenton Potteries Co., 273 U.S. 392, 397-98 (1927).

110. 340 U.S. 211 (1951).

111. "[Agreements to fix maximum prices] no less than those to fix minimum prices, cripple the freedom of traders and thereby restrain their ability to sell in accordance with their own judgment. "Kiefer-Stewart Co. v. Seagram \& Sons, 340 U.S. 211, 213 (1951).

112. Albrecht v. Herald Co., 390 U.S. 145, 152-53 (1968).

113. Id. 
Albrecht involved a metropolitan newspaper cancelling the distributorship of a company, which delivered its papers, because the company refused to comply with the maximum subscription prices which the newspaper had set. Following a rather shallow analysis which relied for the most part on Kiefer-Stewart, the majority of the Court held that the newspaper's attempt to fix maximum prices was per se illegal. Justice Harlan, in a well-reasoned dissent, argued that use of the per se rule was inappropriate. ${ }^{114} \mathrm{He}$ pointed out that because of the nature of the business, the plaintiff-distributor in Albrecht had an exclusive monopoly within a limited geographic area for delivery of the defendant's newspapers. Thus, the only way the newspaper's consumers could be protected from being charged "supercompetitive" prices and the newspaper protected from losing its sales volume-the distributor preferred to make his profit by selling fewer papers at a higher price-was for the newspaper to set a maximum resale price. The distinction between the effect of minimum and maximum pricefixing, explained Justice Harlan, was so significant that the same conclusive presumption of illegality should not be applied to both..$^{115}$ While minimum price floors are invariably harmful on balance, price ceilings do not usually lessen horizontal competition; instead, they drive prices down toward levels that would normally be set by intense competition, thus preventing dealers in a monopoly situation, as was the plaintiff, from reaping monopoly profits. ${ }^{116}$

A second distinction between maximum and minimum pricefixing is that minimum price floors are usually beneficial only to dealers involved in horizontal competition because they assure that even in the most intense competition prices will not be undercut below a certain level. Thus, it is proper in most instances to infer from a minimum price-setting scheme that horizontally competing dealers have conspired to restrain trade ${ }^{117}$ so that a per se prohibition is justified. However, maximum price-setting plans do nothing to lessen the price competition between horizontally competing dealers, and

\section{Id. at $156-68$.}

115. Id. at $166-67$.

116. In his dissent Justice Stewart noted that the majority found the defendant guilty of not permitting the plaintiff an absolute, uncontrolled monopoly. "The Court in this case," he wrote, "does more, I think than simply depart from the rule of reason. . . . The Court today stands the Sherman Act on its head." Id. at 170.

117. See Turner, supra note 67. Professor Turner argues that what apparently is a unilateral attempt by a manufacturer to impose minimum resale prices by refusing to deal with noncomplying dealers quite often is a tacit agreement between the manufacturer and his dealers to set the minimum price. $I d$. at 689 . 
they are almost always vertically imposed by a manufacturer acting unilaterally to insure that the highest volume of its product sales will be achieved. Therefore, the inference from the existence of a maximum price-setting plan of a conspiracy to restrain trade is clearly not warranted. This being the case, dropping the per se rule and utilizing a standard of proof that would permit the manufacturer to present evidence to justify his price-setting plan would appear sound. If a complete retreat in this situation from the per se rule to the "rule of reason" is a leap which the Court believes it should not undertake, then shifting to a middle position, one in which a rebuttable presumption of illegality would be utilized, appears to be the most sensible step for the Court to take.

Tying Arrangements. One further area in which a rebuttable presumption of illegality might serve as a sound alternative to the present either-or approach involves certain tying arrangements. A tiein is merely a requirement imposed upon a purchaser of one product that he also purchase another, often, but not necessarily, related product from the seller. In the leading tie-in case, Northern Pacific Railway Co. v. United States, ${ }^{118}$ the defendant sold and leased land on the condition that the grantee or lessee use defendant's facilities for shipping all commodities produced or manufactured on the land, provided that defendant's rates and services were no higher than those of competitors. The Supreme Court sustained a summary judgment against the railroad, holding that such tying arrangements were per se violations of section 1 of the Sherman Act. ${ }^{119}$ Since that case the per se rule has been generally utilized in litigation involving tying arrangements. However, peculiar factual situations may render the flat imposition of a per se approach unwise and utilization of rebuttable presumptions of illegality far more judicious.

For example, in 1948 Jerrold Electronics Corporation was formed to produce and sell a newly developed television antenna booster designed to improve television reception in fringe areas by amplifying

118. 356 U.S. 1 (1958).

119. The Court stated:

They [tying arrangements] are unreasonable in and of themselves whenever a party has sufficient economic power with respect to the tying product to appreciably restrain frce competition in the market for the tied product and a "not insubstantial" amount of interstate commerce is affected. Id. at 6 .

See also International Salt Co., Inc. v. United States, 332 U.S. 392 (1947); International Business Machs. Corp. v. United States, 298 U.S. 131 (1936); Turner, The Validity of Tying Arrangements Under the Antitrust Laws, 72 HARv. L. REv. 50 (1958). 
the weak signals already available there. After a few initial successes had been widely publicized, representatives of a large number of communities in the fringe areas pressed Jerrold to install complete community antenna systems in their towns. The systems were highly technical and involved extremely sensitive and complicated equipment. Jerrold was one of the first companies in a new industry with vast potential, but its owners knew that a few major failures at the outset would damage its reputation and thus might jeopardize the company's entire future. They therefore decided to sell the antennas only to purchasing groups that would agree to have all installation and servicing of the equipment done by Jerrold servicemen. To complement this policy the company refused to sell the components of its system piecemeal, requiring the purchaser to obtain the entire package from Jerrold. In 1957 the United States Government brought suit against Jerrold, alleging that the requirement that purchasers of the Jerrold antennas also have all installation and servicing done by Jerrold, and that Jerrold's refusal to sell parts of its system other than as a complete package, constituted tying arrangements and thus were per se violations of section 1 of the Sherman Act.

The district court opinion in United States v. Jerrold Electronics Corp..$^{120}$ acknowledged that, although the per se rule was usually applied to such arrangements and the necessary prerequisites for imposition of the rule"21 had been established, because of the "rather unique circumstances" in the case another approach would be utilized. ${ }^{122}$ Under traditional antitrust theory, if the per se approach is abandoned, then the "rule of reason" comes into play, the plaintiff having the burden of proving that the defendant's practices are unreasonable restraints on trade. However, Judge Van Dusen, rejecting this either-or approach, held that the per se rule was not applicable because of the peculiar factual setting, and thus the defendant, not the plaintiff, should bear the burden of proving that its actions were not

120. 187 F. Supp. 545 (E.D. Pa. 1960), affd 365 U.S. 567 (1961).

121. See notes 118-19 supra.

122. 187 F. Supp. 545 at 556 . The court reasoned:

Any judicially, as opposed to legislatively, declared per se rule is not conclusively binding on this court as to any set of facts not basically the same as those in the cases in which the rule was applied . . . . Therefore, while the per se rule should be followed in almost all cases, the court must always be conscious of the fact that a case might arise in which the facts indicate that an injustice would be done by blindly accepting the per se rule. Id. 
unreasonable. ${ }^{123}$ Analytically, upon a showing of actions generally considered violative per se of the antitrust laws, a rebuttable presumption of illegality was held to have arisen in favor of the Government, which could only be overcome by defendant's proof of facts sufficient to demonstrate that its actions were not unreasonable commercial restraints. Because, as Judge Van Dusen pointed out, the tiein was instituted in the launching of a new business with a highly uncertain future, it was necessary to insure that the defendant's reputation was not irreparably damaged by early failures resulting from improper installation and servicing by independent servicemen. ${ }^{124}$ Undoubtedly Judge Van Dusen was correct in assessing that use of the per se rule in such a situation would have been sacrificing a reasonable business practice to an inappropriate but supposedly controlling legal structure. ${ }^{125}$

\section{Conclusion}

The antitrust statutes that Congress has formulated set forth general directives for courts to follow in the policing of competition within the American economy. Congress left to the courts the job of fashioning precise substantive rules to allocate the burden of proof in suits arising under those statutes, and the courts have responded with notable insight in developing an irrebuttable presumption in the form of the per se rule from the original "rule of reason." However, many years have passed since the per se rule was added as an alternative in allocating the burden of proof in antitrust litigation. Years of additional adjudication have demonstrated that freezing the allocation within the either-or option embodied by the "rule of reason" and the per se rule may have resulted in an undesirable rigidity.

Utilization of a rebuttable presumption of illegality that shifts the burden of proof to the defendant is a third alternative which should be adopted by the courts as a necessary complement to the burden of proof rules now being used in antitrust litigation. Adoption of such an approach would maintain the courts' flexibility in formulating rules of procedure in this important area of law. It would also place

123. Id. at 560 .

124. Id. at 557 .

125. The Supreme Court has apparently sanctioned Judge Van Dusen's approach, by citing the Jerrold case for the proposition that in cases involving a small company attempting to break into or stay in business, something less than a per se approach might be appropriate. White Motor Co. v. United States, 372 U.S. 253, 263 (1963). 
the burden of proof in many situations upon the party who, because of its sole access to information, should be required to shoulder such a burden. In addition, adoption of such a rule would permit the courts to protect adequately the vital American interest in open and competitive enterprise, an interest which is being challenged by novel commercial practices whose total economic effects are still too unclear to warrant being declared inherently inimicable but nevertheless pose obvious and significant dangers to unfettered trade. Finally, such an approach would put an end to the gross injustice of utilizing the per se rule in exceptional situations to prohibit a defendant from presenting evidence which could clearly demonstrate that on balance the effect of the challenged practice is to foster rather than to inhibit the competitive forces of the marketplace. 
